\title{
Hyaluronic acid used for the correction of nasal deviation in an 18-year-old Middle Eastern man
}

\author{
JR Piggott BSc(Hons), A Yazdani MD FRCSC
}

\begin{abstract}
JR Piggott, A Yazdani. Hyaluronic acid used for the correction of nasal deviation in an 18-year-old Middle Eastern man. Can J Plast Surg 2011;19(4):156-158.

The use of fillers for nonsurgical rhinoplasty has advanced in both materials and methods, and continues to gain popularity in North America. This technique is most often used for secondary revisions, although reports of fillers used in primary rhinoplasty in selected patients have been recently described. The present report details the use of a hyaluronic acid dermal filler in a young Middle Eastern man for a post-traumatic crooked nose deformity. Primary correction of the patient's right-sided nasal bone deviation using hyaluronic acid as a soft tissue filler was achieved with excellent results and patient satisfaction. The current use of fillers in nasal contouring is reviewed.
\end{abstract}

Key Words: Deviated nose; Fillers; Hyaluronic acid; Middle Eastern nose; Rhinoplasty

Cor decades, soft tissue fillers have been used by plastic surgeons for a variety of facial contouring and correction procedures $(1,2)$. Fillers are a favoured method for wrinkle reduction, scar correction and soft tissue augmentation because they reliably produce good results with few complications $(1,2)$. The excellent outcomes with filler materials has led to its current surge in popularity in North America. In addition to using filler countouring for standard procedures, plastic surgeons and dermatologists have begun to consider new uses for soft tissue fillers (1-5).

Soft tissue filler injection has been adopted by several surgeons as a method of correcting deformities of the nose (1-5). The main indications are correction of remaining asymmetries and contour irregularities in the postoperative rhinoplasty patient $(2,4)$. Although the number of reports of fillers used for primary rhinoplasty are few, a small number of surgeons have recently described excellent outcomes in selected patients using this method $(1,3,5)$. Despite their reported success, the use of fillers for primary rhinoplasty is only beginning to gain recognition, and currently remains relatively undocumented.

The Middle Eastern nose poses several challenges to the plastic surgeon. When performing rhinoplasty in a Middle Eastern patient, the surgeon must avoid the production of an 'over-operated' nose by changing the characteristic Middle Eastern features too dramatically (6-9). Important anatomical characteristics common to the Middle Eastern nose include a prominent dorsum, wide nasal vaults, a high and shallow radix, and a droopy, undefined nasal tip (6-9). Patients commonly wish to retain much of their natural ethnic appearance $(6,10)$. Furthermore, male patients are frequently more hesitant to commit to surgery because of concerns regarding the preservation of a masculine nose $(6,10)$.

The reluctance of male Middle Eastern patients to alter both their Middle Eastern and their masculine features suggests that surgical rhinoplasty and its permanent and more substantial changes may not be the most suitable option for all patients $(7,9)$. We report a case of nonsurgical rhinoplasty using hyaluronic acid in a young Middle Eastern man with a right-sided nasal deviation.

\author{
L'acide hyaluronique pour corriger une déviation \\ nasale chez un homme moyen-oriental de 18 ans
}

Les méthodes et les matériaux utilisés dans les produits de comblement pour la rhinoplastie non chirurgicale ont progressé et continuent de gagner en popularité en Amérique du Nord. La technique sert surtout dans le cadre de révisions secondaires, mais des rapports de produits de comblement utilisés lors rhinoplasties primaires chez des patients sélectionnés ont récemment été publiés. Le présent rapport détaille l'utilisation d'un produit de comblement dermique à l'acide hyaluronique chez un jeune homme moyen-oriental afin de corriger une difformité nasale post-traumatique. La correction primaire de la déviation de l'os nasal droit du patient à l'aide d'acide hyaluronique et d'un produit de comblement des tissus mous a donné d'excellents résultats et su obtenir la satisfaction du patient. L'utilisation actuelle des produits de comblement pour la plastie du nez est exposée.

Victoria Hospital, London Health Sciences Centre, London, Ontario

Correspondence: Dr Arjan Yazdani, Victoria Hospital, London Health Sciences Centre, 800 Commissioners Road East,

Room E2-214, PO Box 5010, London, Ontario N6A 5W9. Telephone 519-685-8320, fax 519-695-8322, e-mail arjang.yazdani@lhsc.on.ca 




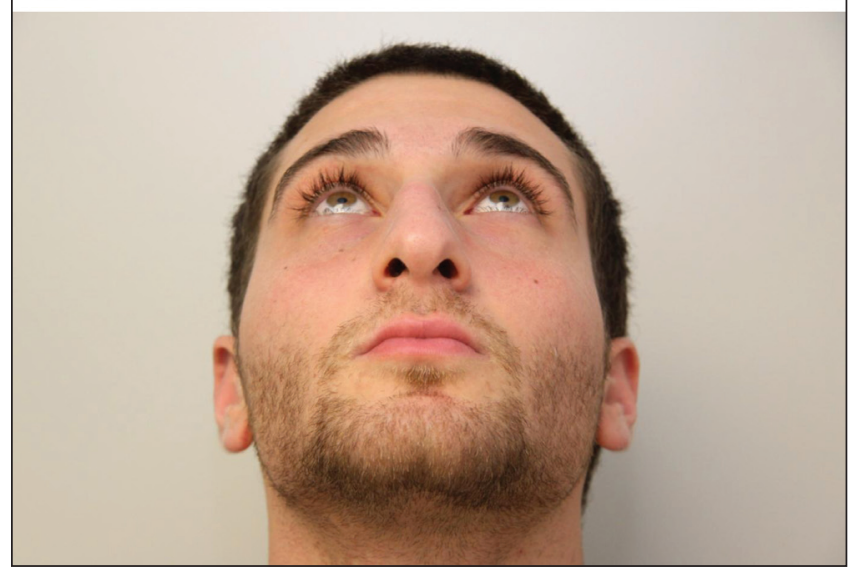

Figure 1) Before augmentation with hyaluronic acid for right-sided nasal deformity: Left nasal bone depression and prominent dorsal hump

results with few complications and high patient satisfaction rates $(2,4)$.

In our patient, several indications resulted in the decision to offer filler rhinoplasty. Although our patient desired cosmetic improvement of his right-sided deviation, he was not interested in surgical rhinoplasty. His concern related to his desire to retain his Middle Eastern appearance. Because he was free of functional airway issues, his irregularities were minor and he was uninterested in surgery, we deemed him to be a suitable candidate for filler correction. The right-sided nasal deviation was corrected with filler augmentation over the left dorsum. His radix was augmented to correct for the large dorsal hump - a technique previously described by others $(1,3)$. Patient satisfaction was high.

In contrast to the more common use of fillers as a means of secondary correction, fillers were used for primary rhinoplasty in the present

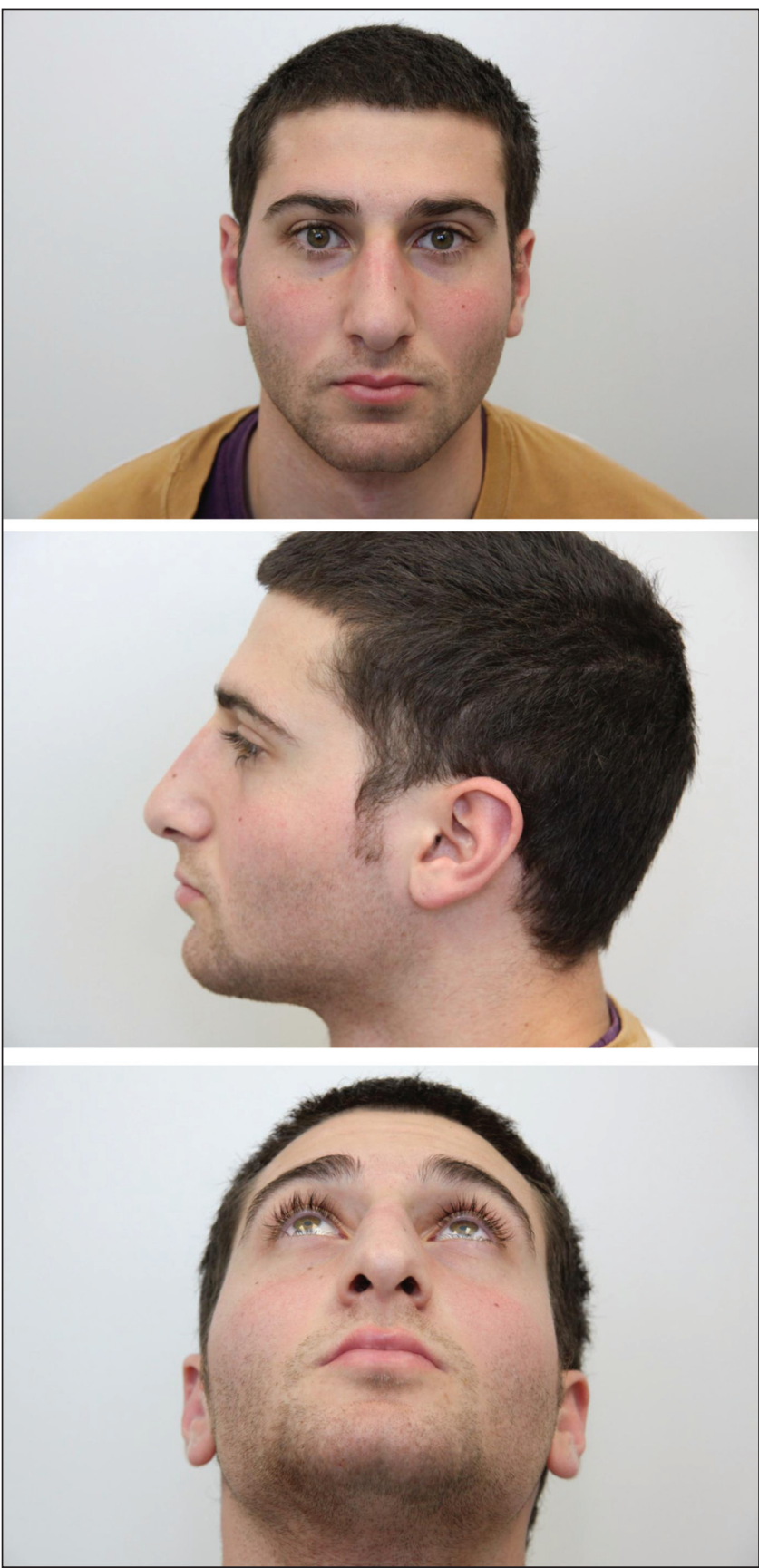

Figure 2) After augmentation with hyaluronic acid for right-sided nasal deformity: Corrected left nasal bone depression and augmented radix

case. Although uncommon, several other surgeons have described their outcomes using fillers as a primary technique. Both Rokhsar and Ciocon (3) and De Lacerda and Zancanaro (1) have reported using calcium hydroxylapatite and hyaluronic acid, respectively, in patients desiring a thinner nose. Both articles describe using fillers to straighten and augment the nasal dorsum, creating the appearance of a slimmer nose. Redaelli (5) proposed a role for filler rhinoplasty to augment the aging nose, which is often subject to reduction of bone mass and subcutaneous tissues. He also described the effectiveness of combining hyaluronic acids with botulinum toxin A for paralysis of the depressor septi nasal muscle, for correction of a droopy nasal tip. Again, all reports suggest that the use of filler materials are most successful when used for minor alterations $(1,3,5)$.

Rejection of surgical methods, for a variety of reasons, may prompt the plastic surgeon to consider filler rhinoplasty as an alternative. The 
patient in our case was a Middle Eastern man who refused surgical rhinoplasty but still wished to correct the cosmetic appearance of his nose. Reduced costs, avoidance of general anesthesia and minimal recovery time are other benefits of filler methods compared with surgical rhinoplasty $(3,4)$. Humphrey et al $(4)$ consider patients with defects of the dorsum, such as our patient, to be ideal candidates for filler correction. Fillers may be an excellent option for patients unfit for surgery, or patients who do not want to undergo a surgical procedure.

We suggest that nonsurgical rhinoplasty using soft tissue fillers be considered in selected patients who plan to make only minor alterations, and for patients who, for other reasons - medical, financial or personal preference - wish to avoid surgical methods.

\section{CONCLUSION}

Fillers may be a good alternative for patients who require only small alterations to correct nasal depressions or deformities. Nonsurgical rhinoplasty using fillers offers a less invasive, nonpermanent and more affordable method of primary correction for patients who are not interested in surgical alternatives.

DISCLOSURE: The authors have no conflicts of interest to declare.

\section{REFERENCES}

1. De Lacerda DA, Zancanaro P. Filler rhinoplasty. Dermatol Surg 2007;33:S207-12.

2. Stupak HD, Moulthrop TH, Wheatley P, Tayuman AV, Johnson CM. Calcium hydroxylapatite gel (Radiesse) injection for the correction of postrhinoplasty contour deficiencies and asymmetries. Plast Reconstr Surg 2007;120:55S-66S.

3. Rokhsar C, Ciocon DH. Nonsurgical rhinoplasty: An evaluation of injectable calcium hydroxylapatite filler for nasal contouring. Dermatol Surg 2008;34:994-6.

4. Humphrey CD, Arkins JP, Dayan SH. Soft tissue fillers in the nose. Asthet Surg J 2009;29:477-84.

5. Redaelli A. Medical rhinoplasty with hyaluronic acid and botulinum toxin A: A very simple and quite effective technique. J Cosmet Dermatol 2008;7:210-20.

6. Rohrich RJ, Ghavami A. Rhinoplasty for Middle Eastern noses. Plast Reconstr Surg 2007;123:1343-54.

7. Daniel RK. Middle Eastern rhinoplasty in the United States: Part 1. Primary rhinoplasty. Plast Reconstr Surg 2009;124:1630-9.

8. Daniel RK. Middle Eastern rhinoplasty in the United States: Part II. Secondary rhinoplasty. Plast Reconstr Surg 2009;124:1640-8.

9. Ghavami A, Rohrich RJ. Middle Eastern rhinoplasty in the United States: Part 2. Secondary rhinoplasty. Plast Reconstr Surg 2009;124:1649-51.

10. Rohrich RJ, Janis JE, Kenkel JM. Male rhinoplasty. Plast Reconstr Surg 2003;112:1071-85. 